\title{
HUBUNGAN FAKTOR KEPRIBADIAN EXTRAVERSION DAN PRESTASI AKADEMIK
}

\author{
Luthfiyatul Badriyah $^{1}$ dan Andi Tenri Faradiba ${ }^{2}$ \\ ${ }^{1}$ Fakultas Psikologi, Universitas Pancasila \\ Email: Luthfiyatulb1997@gmail.com \\ ${ }^{2}$ Fakultas Psikologi, Universitas Pancasila \\ Email: atenri.frd@gmail.com
}

\begin{abstract}
ABSTRAK
Prestasi akademik seorang mahasiswa dipengaruhi oleh beberapa faktor yang salah satunya adalah kepribadian. Big five Personality merupakan salah satu teori kepribadian yang paling sering digunakan dalam menjelaskan prestasi akademik pada mahasiswa. Big Five terdiri dari 5 dimensi yaitu, Extraversion, Agreeableness, Conscientiousness, Neuroticism, dan Openness to Experience. Penelitian ini bertujuan untuk melihat hubungan kepribadian extraversion terhadap prestasi akademik.. Sampel dari penelitian ini adalah 640 mahasiswa. NEO-FFI digunakan untuk mengukur kepribadian mahasiswa sedangkan nilai IPK digunakan untuk mengukur prestasi akademik. Analisis korelasional menunjukan hasil bahwa extraversion dengan prestasi akademik memiliki nilai signifikansi sebesar (0,09>0,05) sehingga extraversion ditemukan tidak memiliki korelasi secara signifikan dengan prestasi akademik mahasiswa.
\end{abstract}

Kata kunci: extraversion, prestasi akademik, kepribadian, mahasiswa

\section{PENDAHULUAN}

Dalam rangka menghadapi persaingan global di bidang pendidikan antar perguruan tinggi baik di dalam maupun di luar negeri diperlukan mahasiswa yang memiliki prestasi akademik yang berkompeten sehingga dapat bersaing di kancah nasional maupun internasional. Prestasi akademik itu sendiri merupakan tolak ukur dari hasil pembelajaran yang dilakukan oleh mahasiswa di perguruan tinggi. Untuk melihat pencapaian hasil prestasi akademik yang baik pada mahasiswa, terdapat faktor internal dan faktor eksternal. Faktor internal meliputi, kecerdasan, bakat, minat, usia, motivasi, dan kepribadian, sedangkan faktor eksternal meliputi, kelompok pertemanan, suasana perkuliahan dan masyarakat, perilaku dosen serta waktu pengajaran (Cassidy \& Eachus dalam Permatasari, Prabandari \& Kristina, 2016). Meskipun banyak faktor-faktor yang mempengaruhi prestasi akademik, ada faktor utama yang mempengaruhi prestasi akademik yaitu faktor kepribadian. Feist \& Feist (1998) mendefinisikan kepribadian sebagai sebuah pola yang relatif menetap atau sebuah karakteristik yang dimiliki oleh individu secara konsisten terhadap perilaku.

Teori kepribadian yang paling umum digunakan saat ini adalah teori Big Five Personality yang menjelaskan kepribadian dalam lima faktor (Costa \& McCrae, 1992; Pervin \& John, 2001). Pertama, openness to experiences. Seorang individu dengan skor yang tinggi pada openness to experiences menunjukkan sifat rasa ingin tahu yang besar, minat yang luas, kreatif, imajinatif, dan terbuka terhadap pengalaman atau hal-hal baru. Kedua, conscientiousness. Kepribadian conscientiousness yang tinggi menunjukkan sifat teratur, pekerja keras, dapat diandalkan, disiplin, tepat waktu, dan hatihati. Ketiga, agreeableness. Kepribadian individu dengan agreeableness yang tinggi menunjukkan sifat suka menolong, pemaaf, penurut, dan dapat dipercaya. Keempat, neuroticism. Kepribadian ini menunjukkan sifat mudah cemas, gugup, emosional, merasa tidak aman, merasa tidak mampu, dan mudah panik. Kemudian yang terakhir adalah extraversion. Kepribadian extraversion yang lebih 
tinggi menunjukkan sifat yang mudah menyesuaikan diri dengan lingkungan sosial, aktif, banyak berbicara, orientasi pada hubungan bersama, penuh kasih sayang, ramah, energik, dan tertarik pada banyak hal. Faktor kepribadian extraversion ini dikatakan mempengaruhi prestasi akademik, dikarenakan individu yang memiliki kepribadian ini cenderung ramah, terbuka, dan mudah berinteraksi dengan orang lain, adanya interaksi dengan orang lain, individu akan mampu banyak mendapatkan pengetahuan baru dari orang lain, sehingga dengan keramahan tersebut dalam berinteraksi dengan orang lain, ia cenderung terbuka dan tidak sungkan untuk berbagi pengetahuan yang dimilikinya. Dibandingkan dengan kepribadian yang introvert, ia lebih berfokus ke dalam dirinya. Cenderung menutup diri, tidak mudah menyesuaikan diri dengan lingkungan baru, tidak banyak berbicara. Saat ini banyak yang menganggap bahwa individu yang cenderung terbuka dianggap lebih kompeten dalam akademiknya, dibandingkan dengan individu yang lebih tertutup, dianggap sebagai individu yang apatis dan tidak berkompeten dalam akademiknya, oleh karena itu peneliti ingin mengetahui apakah ada hubungan faktor kepribadian extraversion terhadap prestasi akademik.

Berdasarkan penelitian sebelumnya, menurut Beaujean et al. (2011) menemukan bahwa prestasi akademik tidak berhubungan dengan extraversion. Di sisi lain, dalam penelitian menurut Caprara, Vecchione, Alessandri, Gerbindo \& Barbaranelli (2011) menemukan bahwa extraversion berhubungan dengan prestasi akademik walaupun dengan cara yang berbeda-beda dari setiap individu. Lebih lanjut, dalam penelitian Premuzic \& Furnham (2003) menemukan bahwa faktor extraversion memiliki hubungan secara positif dengan prestasi akademik saat sekolah dasar, tetapi setelah pasca sekolah hubungan tersebut memiliki hasil yang lebih beragam. Adanya perbedaan penemuan dari penelitian-penelitian sebelumnya menjadikan penelitian ini penting untuk dilakukan guna mengetahui hubungan antara faktor kepribadian extraversion dan prestasi akademik.

\section{Faktor kepribadian extraversion}

Faktor extraversion adalah menilai kuantitas dan intensitas interaksi secara interpersonal, level aktivitasnya, kebutuhan untuk didukung, kemampuan untuk berbahagia (Pervin \& John, 2001). Faktor kepribadian extraversion dikatakan mampu mempengaruhi pencapaian prestasi akademik dikarenakan individu yang memiliki dimensi kepribadian tersebut cenderung ramah, terbuka, mudah menyesuaikan diri dengan lingkungan sosial, aktif, banyak berbicara, dan mudah berinteraksi dengan orang lain. Ketika ia berinteraksi dengan orang lain, ia mampu menangkap banyak pengetahuan baru dari orang lain yang dapat menambah informasi mengenai pengetahuan sebelumnya, dan karena keramahannya tersebut, orang yang berinteraksi dengannya cenderung terbuka dan tidak sungkan untuk berbagi pengetahuan yang dimilikinya terhadap pemilik dimensi kepribadian tersebut.

\section{Prestasi akademik}

Menurut perspektif kognitif sosial, prestasi akademik dipandang sebagai hubungan yang kompleks antara kemampuan individu, persepsi diri, penilaian terhadap tugas, harapan akan kesuksesan, strategi kognitif dan regulasi diri, gender, gaya pengasuhan, status sosioekonomi, kinerja dan sikap individu terhadap sekolah (Clemons, 2008).

Dengan demikian, dapat disebutkan bahwa model teoritis yang dapat menunjukkan faktor stimulus dan faktor proses internal yang paling berperan dalam pencapaian prestasi akademik. Di samping faktor-faktor tersebut, Bandura (1986) mengemukakan bahwa faktor personal internal yang sangat berperan dalam pencapaian prestasi akademik adalah efikasi diri dan harapan-harapan. 


\title{
2. METODE PENELITIAN
}

\section{Karakteristik partisipan}

Karakteristik partisipan dalam penelitian ini adalah mahasiswa aktif minimal kuliah pada tahun kedua dengan rata-rata usia 19 - 20 tahun, jumlah partisipan 265 orang laki-laki dan 375 orang perempuan, dengan total 640 partisipan. Teknik pengambilan sampel menggunakan teknik non-probability sampling, yaitu accidental sampling. Partisipan dalam penelitian ini berasal dari dua Universitas yang berbeda di Jakarta.

\begin{abstract}
Alat ukur
Dalam penelitian ini peneliti menggunakan alat ukur untuk mengukur prestasi akademik, menggunakan IPK (Indeks Prestasi Kumulatif). Sedangkan untuk mengukur faktor kepribadian menggunakan alat ukur NEO FFI ( Neuriticism, Extraversion, Openness to Experience Five Factor Inventory), yang terdiri dari 12 item Extraversion. Contoh item adalah saya senang berbincang dengan banyak orang yang berbeda.
\end{abstract}

\section{Prosedur}

Partisipan berjumlah 640 mahasiswa. Mahasiswa diberikan petunjuk untuk mengisi alat ukur kepribadian yang menggunakan lima poin skala Likert. Jika item dianggap sesuai dengan diri partisipan, mereka diminta melingkari angka 5 (sangat sesuai). Selain itu, partisipan diminta untuk menuliskan Indeks Prestasi Kumulatif (IPK) yang diperoleh. Agar menghindari ketidakjujuran partisipan dalam mengisi IPK, mereka diberi informasi bahwa keterlibatan mereka dalam penelitian tidak akan berpengaruh pada proses perkuliahan dan penilaian. Setelah data terkumpul, analisis uji korelasi dilakukan dengan menggunakan SPSS 22 for Windows.

\section{HASIL DAN PEMBAHASAN}

Sebelum digunakan, peneliti menguji alat ukur faktor kepribadian extraversion untuk melihat 12 item yang ada apakah benar hanya mengukur extraversion dengan menggunakan software Lisrel. Dari hasil analisis CFA yang dilakukan dengan model 1 faktor ditemukan model yang tidak fit dengan nilai chisquare $=730,72$, karena hasil tidak fit, peneliti melakukan model fit sebanyak 12 kali sehingga menghasilkan model fit sebesar 0,046. Lalu, peneliti melakukan modifikasi terhadap model, dimana kesalahan pengukuran pada beberapa item dibebaskan berkorelasi satu sama lainnya sehingga diperoleh model fit dengan nilai chi-square sebesar 99,71. Nilai chi-square menghasilkan RMSEA lebih kecil dari 0,05 yang artinya seluruh item memang mengukur satu faktor saja, yaitu extraversion. Langkah selanjutnya ialah melihat valid tidaknya item tersebut dengan mengukur faktor yang hendak diukur, sekaligus menentukan apakah item tersebut perlu dihilangkan atau dipertahankan, maka dilakukan pengujian hipotesis nihil mengenai coefficient muatan faktor dari item. Pengujiannya dilakukan dengan melihat $t$-value untuk setiap coefficient muatan faktor. Hasilnya ditemukan bahwa seluruh item dinyatakan valid.

Dari hasil uji korelasi antara faktor kepribadian extraversion dan prestasi akademik didapati tidak ada hubungan antara extraversion dan prestasi akademik. Pada penelitian sebelumnya, O'Connor \& Panonen's (2007) menemukan bahwa prestasi akademik tidak berhubungan dengan Extraversion, Openness to Exprerience, Agreableness, dan Neuroticisim. Kemudian, dalam penelitian menurut Caprara et al. (2011), ditemukan bahwa extraversion berhubungan dengan prestasi akademik walaupun dengan cara yang berbeda-beda dari setiap individu. Premuzic \& Furnham (2003) 
menemukan bahwa extraversion memiliki hubungan secara positif dengan prestasi akademik saat sekolah dasar, tetapi setelah pasca sekolah, hubungan tersebut memiliki hasil yang lebih beragam. Kecenderungan ramah, mudah menyesuaikan diri dengan orang yang baru dikenal, dan mudah bersahabat tidak memiliki kerterkaitan dengan prestasi akademik di perkuliahan yang diukur melalui Indeks Prestasi Kumulatif. Hal ini dapat dijelaskan melalui sistem pembelajaran di perkuliahan yang menganut sistem yang berpusat pada mahasiswa dan belajar mandiri sehingga bagaimana pun hubungan pertemanan yang dimiliki tidak memberikan peran terhadap prestasi akademik. Lebih lanjut, penilaian kemampuan dan kompetensi di tingkat kuliah lebih banyak mengacu pada penilaian individual sehingga yang lebih berperan adalah kemauan dan usaha yang dilakukan oleh mahasiswa itu sendiri. kemudian saat perkuliahan individu memiliki kebebasan dalam menentukan tujuan akademik sendiri yang cenderung berbeda antar mahasiswa bahkan dalam hubungan pertemanan. Karena memang, saat individu memutuskan untuk melanjutkan pendidikan di perguruan tinggi, ia memiliki tujuan yang berbeda-beda untuk mencapai akademiknya, target kelulusan dan kategori kelulusan, yaitu baik, sedang atau sangat baik.

Selain kepribadian, ada faktor lain yang dapat mempengaruhi prestasi akademik mahasiswa, yaitu motivasi untuk berprestasi, keyakinan terhadap kemampuan, kemandirian (Wahyuni dalam Maslihah , 2011). Prestasi akademik partisipan dalam penelitian ini dapat dipengaruhi oleh beberapa faktor tersebut sehingga dapat dijadikan bahan pertimbangan untuk melakukan penelitian berikutnya. Selain itu, peran faktor kepribadian lainnya seperti conscientiousness, opennes to experience, neuroticism, dan agreeableness juga dapat dijadikan sebagai bahan penelitian berikutnya.

\section{KESIMPULAN DAN SARAN}

Dengan demikian, dapat disimpulkan bahwa hasil korelasi tidak signifikan antara faktor kepribadian extraversion terhadap prestasi akademik dengan nilai sig. $(0,090>0,05)$. Dari kesimpulan diatas dapat diartikan bahwa pencapaian akademik individu dapat dipengaruhi beberapa faktor salah satunya faktor kepribadian extraversion walaupun dengan cara yang beragam dan setiap individu mengembangkan dengan cara yang berbeda. Dapat disarankan bahwa untuk penelitian selanjutnya diharapkan bisa menggunakan karakteristik responden yang lebih bervariasi tidak hanya pada mahasiswa saja, dan memperbesar jumlah sampel penelitian agar mendapatkan hasil yang lebih akurat dan lebih beragam, sehingga faktor kepribadian extraversion terhadap prestasi akademik dapat memiliki hubungan yang signifikan. Mengingat dari penelitian sebelumnya, penelitian mengenai faktor kepribadian extraversion terhadap prestasi akademik masih jarang yang menemukan adanya hubungan yang terakit akan hal tersebut. Walaupun peneliti melakukan upaya untuk meminimalkan bias terhadap nilai IPK yang ditulis sendiri oleh partisipan, penelitian berikutnya disarankan untuk memperoleh data prestasi akademik langsung dari sistem akademik universitas terkait, untuk menghindarkan bias dari partisipan.

\section{Ucapan Terima Kasih (Acknowledgement)}

Peneliti mengucapkan terima kasih kepada seluruh partisipan yang sudah bersedia berpartisipasi dalam penelitian kali ini dan pihak-pihak yang telah membantu dalam penyusunan artikel ini. 


\section{REFERENSI}

Bandura, A. (1986). Social Foundations of Thought and Action: A Social Cognitive Theory. Englewood Cliffs, NJ, US: Prentice-Hall.

Beaujean, A.A., Firmin, M.W., Attai, S., Johnson, C.B., Firmin, R.L., \& Mena, K.E. (2011). Using personality and cognitive ability to predict academic achievement in a young adult sample. Personality and Individual Differences, 51(6), 709-714. doi : 10.1016/j.paid.2011.06.023.

Caprara, G.V., Vecchione, M., Alesandri,G., Gerbino, M., \& Barbaranelli, C. (2011). The contribution of personality traits and self-efficacy believes to academic achievement: A longitudinal study. British Journal Of Educational Psychology, 81(1),78-96. doi : 10.1348/2044-8279.002004.

Clemons, T.L. (2008). Underachieving gifted students: a social cognitive model. The National Research Centre On The Gifted And Talented. Retrieved from https://eric.ed.gov/?id=ED505382.

Day, L., Hanson, K., Maltby, J., Proctor, C., \& Wood, A. (2010). Hope uniquely predicts objective academic achievement above intelligence, personality, and previous academic achievement. Journal of Research in Personality, 44(4), 550-553. doi : 10.1016/j.jrp.2010.05.009.

Feist, J. \& Feist, G.J. (1998). Theories of Personality (4 ${ }^{\text {th }}$ ed.). New York, NY: McGraw Hill Company.

Maslihah, S. (2011). Studi tentang hubungan dukungan sosial, penyesuaian sosial di lingkungan sekolah dan prestasi akademik siswa SMPIT Assyfa Boarding School Subang Jawa Barat. Jurnal Psikologi, 10(2), 103-114. doi : 10.14710/jpu.10.2.103-114. 